\title{
Harapan dan Kenyataan: Implementasi Reformasi Agraria di Provinsi Riau
}

\author{
Gevisioner \\ Badan Penelitian dan Pengembangan Provinsi Riau \\ * irgevisioner@gmail.com
}

\begin{abstract}
Abstrak. Ketidakseimbangan pemilikan tanah paling banyak menimbulkan masalah dan mensengsarakan rakyat hingga saat ini. Tulisan ini mencoba menelaahan implementasi kebijakan reformasi agraria dan permasalahannya di Provinsi Riau dalam bentuk model policy paper. Implementasi reformasi agraria di provinsi Riau hingga saat ini dapat dikatakan sama sekali macet dalam pelaksanaannya, hal ini terutama disebabkan oleh kurangnya kemauan politik pemerintah daerah serta kebijakan pembangunan yang lebih mengarah pada upaya mengejar pertumbuhan tanpa memperhatikan pemerataan ekonomi. Sehingga diperlukan sebuah alternatif strategi pembangunan agraria yang diwujudkan dalam reformasi agraria melalui membangun Sistem Informasi Pertanahan (SIP) yang berbasis desa/kelurahan pada pemerintahan kabupaten/kota.
\end{abstract}

Kata Kunci: Reformasi agraria, sistem informasi, konflik, kemiskinan

\section{PENDAHULUAN}

Ketidakseimbangan pemilikan tanah (agraria) dari dulu hingga sekarang, paling banyak menimbulkan masalah dan penyengsaraan rakyat. Sebaliknya indikas kesejahteraan rakyat di suatu negara ditentukan oleh adanya pemerataan pemilikan dan penguasaan agraria negara tersebut. Bahwa kemudian reformasi agraria (land reform) dianggap sebagai kata kunci untuk keberhasilan pembangunan merupakan hal yang sangat beralasan (Sembiring, 2009). Oleh sebab itu, setiap negara berupaya mengatur penguasaan tanah dan tata kelolanya bagi kesejahteraan rakyat untuk pertumbuhan ekonomi nasional, pemerataan pembangunan nasional (Lemhamnas, 2014).

Sebagai sebuah titik awal pembangunan bangsa, reformasi agraria telah menjadi upaya-upaya negara dalam mewujudkan keadilan dan kedaulatan pangan. Reformasi Agraria sendiri tentunya lebih menjadi program utama negara-negara agraris tentunya seperti halnya Indonesia. Adapun sejarah kebijakan agraria di Indonesia (BPN, 2007)

Harapan dari implementasi kebijakan land reform Indonesia, menurut (Harsono, 2003) adalah untuk mempertinggi penghasilan dan taraf hidup para penggarap petani, sebagai landasan atau prasyarat untuk menyelenggarakan pembangunan ekonomi menuju masyarakat adil dan makmur berdasarkan Pancasila. Namun belum kita lihat adanya hasil dari pembentukan program land refom ini. Malah yang muncul adalah semakin menumpuknya masaalah pertanahan tidak bisa dilepas dari macetnya pelaksanaan landreform di Indonesia.

Dibandingkan 2015, jumlah konflik agraria meningkat dua kali lipat sepanjang tahun 2016. Konsorsium Pembaruan Agraria (KPA) mencatat konflik agraria tersebar di 34 provinsi dengan 6 provinsi menyumbang konflik tertinggi. Posisi pertama wilayah dengan konflik agraria terbanyak adalah Riau dengan 44 konflik atau 9,78 persen. Dalam dalam 3 tahun terakhir Provinsi Riau selalu menempati peringkat teratas, dengan perkebunan kelapa sawit terbesar yaitu 2,4 juta hektar. Ekspansi perusahaan perkebunan kelapa sawit dan hutan tanaman industri (HTl) menjadi penyebab utama konflik agraria di provinsi ini. Hal tersebut merupakan akibat dari keputusan pejabat publik yang memberikan izin-izin konsesi kepada perusahaan. Izin ini diberikan di atas tanah-tanah yang sesungguhnnya telah dikuasai dan digarap warga setempat (Ramadhiani, 2017).

Pembaruan agraria dipercayai sebagai proses perombakan dan pembangunan kembali struktur sosial masyarakat, khususnya masyarakat pedesaan, sehingga tercipta dasar pertanian yang sehat, terjaminnya 
kepastian penguasaan atas tanah bagi rakyat sebagai sumberdaya kehidupan mereka, sistem kesejahteraan sosial dan jaminan sosial bagi rakyat pedesaan, serta penggunaan sumberdaya alam sebesar-besarnya untuk kemakmuran rakyat (Sodiki, 2014). Kondisi ini menarik bagi penulis untuk mereview pelaksanaan kebijakan reformasi agraria dan bagaimana strategi dalam menjalankan reformasi agraria guna mewujudkan pembangunan di Provinsi Riau.

\section{KAJIAN PUSTAKA}

Pembangunan mewujudkan masyarakat yang adil dan sejahtera di suatu negara haruslah memperhatikan beberapa hal pokok yaitu sumber daya manusia sebagai anggota masyarakat yang akan mengelola sumber daya alam (bumi, air, ruang angkasa dan kekayaan alam yang terkandung didalamnya) yang disebut agraria dalam arti luas serta hubungan manusia dengan sumber-sumber daya alam termasuk didalamnya mewujudkan keadilan dalam mendapatklan kesempatan memperoleh manfaat dari agraria tersebut. Oleh sebab itu pembangunan di negara-negara berkembang tidak dapat dilakukan tanpa terlebih dahulu melakukan transformasi masyarakat melalui penataan struktur agraria (Noer, 1999).

Krisis pangan pada periode 2007/2008 juga ada kaitannya dengan stategi atau orientasi pengembangan pertanian yang diterapkan/dianjurkan oleh lembaga-lembaga dunia, yang lebih memperioritaskan agroindustri berorientasi pasar dunia dan menjadi penyuplai jaringan supermarket global. Dengan demikian merupakan pertanda bahwa pembangunan pertanian mulai terpuruk karena pondasi yang kurang kuat sehingga bangunan tersebut runtuh (Tulus, 2010). Menurut (Sukino, 2013) mengungkapkan bahwa hal ini disebabkan kekeliruan pembangunan yang dilaksanakan selama ini. Kekeliruan pembangunan yang mendasar adalah tidak ditempatkannya pembaruan agraria yang berupa penataan kembali penguasaan, penggunaan, pemanfaatan, peruntukan dan pemeliharaan sumber-sumber agraria sebagai pra-kondisi dari pembangunan nasional.

Reformasi agraria (land reform) adalah adalah penataan ulang struktur pemilikan dan penguasaan tanah beserta seluruh paket penunjang secara lengkap. Paket penunjang tersebut adalah adanya jaminan hukum atas hak yang diberikan, tersediaanya kredit yang terjangkau, adanya akses terhadap jasa-jasa advokasi, akses terhadap informasi baru dan teknologi, pendidikan dan latihan, dan adanya akses terhadap bermacam sarana produksi dan bantuan pemasaran (Wiradi, 2000). Sedangkan (Winoto, 2006) mengatakan bahwa land reform adalah pembaruan agraria karena apa yang dimaksudkan lebih luas dari sekedar pembagian tanah.

Land reform merupakan penyelesaian yang muncul terhadap masalah ketimpangan struktur agraria, kemiskinan ketahanan pangan, dan pengembangan wilayah pedesaan di berbagai belahan dunia. Banyak negara, baik yang mempunyai ideologi kanan seperti: Jepang, Taiwan, Korea Selatan, Filipina dan Brazil, maupun yang mempunyai ideologi kiri seperti: Cina dan Vietnam melaksanakan Land reform, dengan hasil yang beragam. Tercatat beberapa negara melaksanakan Land Reform lebih dari satu kali seperti Rusia, Jepang, Mexico dan Venezuela (BPN, 2007).

Sebagai sebuah titik awal pembangunan bangsa, reformasi agraria telah menjadi upaya-upaya negara dalam mewujudkan keadilan dan kedaulatan pangan. Reformasi Agraria sendiri tentunya lebih menjadi program utama negara-negara agraris tentunya seperti halnya Indonesia. Adapun sejarah kebijakan agraria di Indonesia (BPN, 2007) adalah sebagai berikut:

\section{Periode Kolonial}

Pada saat ini kebijakan agraria, dimulai dengan berlakunya Agrarische Wet tahun 1870, Pemerintah Kolonial Belanda mengeluarkan Ordonansi Staatblad 1823 Nomor 164. Ketika masa penjajahan Belanda digantikan oleh Jepang pada 1942. Pada masa penjajahan Jepang dikeluarkan peraturan yang melarang pemindahan hak atas benda tetap/ tanah (Osamu Sierei Nomor 2 Tahun 1942). Penguasaan tanah partikelir juga dihapuskan oleh pemerintahan Dai Nippon.

\section{Periode $1945-1960$}

Kebijakan pertanahan periode ini difokuskan pada pembenahan penguasaan dan pemilikan dari sistem kolonialis menjadi sistem nasional. Dalam periode ini penguasaan dan kepemilikan asing dinasionalisasi. Dan penguasaan, pemilikan tanah luas, perdikan, swapraja, partikelir, dan lainnya yang tidak sesuai dengan jiwa kemerdekaan diatur kembali penggunaan dan penguasaanya oleh negara untuk kepentingan nasional

\section{Periode $1960-1967$}

Titik tolak reformasi hukum pertanahan nasional terjadi pada 24 September 1960, yakni disetujuinya dan disahkannya Undang-Undang No. 5 TahunPokok Agraria Undang-Undang Nomor 5 Tahun 1960. Dengan 
berlakunya UUPA tersebut, untuk pertama kalinya pengaturan tanah di Indonesia menggunakan produk hukum nasional yang bersumber dari hukum adat. Dengan ini pula Agrarische Wet dinyatakan dicabut dan tidak berlaku.Di masa ini, kebijakannya melanjutkan kenijakan yang telah dijalankan sebelumnya, dalam periode ini kebijakan diarahkan pada distribusi dan redistribusi tanah oleh negara yang diperuntukkan kepada petani gurem/petani penggarap dan buruh tani. Periode ini dikenal dengan periode Land Reform.

4. Periode $1967-1997$

Sejalan dengan perkembangan dan pertumbuhan ekonomi nasional, pada periode ini pembangunan pertanahan diarahkan untuk mendukung kebijakan penanaman modal atau investasi, tanpa meninggalkan kebijakan untuk sertipikasi tanah-tanah golongan ekonomi lemah.

\section{Periode $1997-2005$}

Di awal era reformasi, kebijakan pertanahan lebih diarahkan pada kebijakan-kebijakan yang langsung menyentuh masyarakat, yang menekankan pada pendaftaran tanah yang dikuasai/dimiliki golongan-golongan tidak mampu.

6. Periode 2005 - sekarang

Pada periode ini, kebijakan pertanahan diarahkan pada "tanah untuk keadilan dan kesejahteraan rakyat". Periode ini ditandai dengan kebijakan penertiban tanah terlantar, penyelesaian sengketa, redistribusi tanah, peningkatan legalisasi aset-tanah masyarakat yang diimplementasikan melalui Reforma Agraria.

Bertolak dari keinginan masyarakat dan keadaan ekonomi Indonesia yang terpuruk sejak 1997 menuntut adanya perubahan politik agraria Indonesia. Strategi pelaksanaan Program Pembaruan Agraria Nasioanal (PPAN) bagaimana yang telah dirumuskan oleh Badan Pertanahan Nasional /BPN (2007). Definisi operasional dari Land Reform sebagai upaya suatu program pemerintah dalam upaya menyelesaikan berbagai permasalahan dengan memberikan sentuhan langsung pada akar permasalahannya adalah: 1) Land Reform merupakan penataan ulang sistem politik dan hukum pertanahan berdasarkan prinsip pasal - pasal UUD 45 dan UUPA ; 2) Land Reform merupakan proses penyelenggaraan Land Reform (LR) dan access reform (AR) secara bersama; LR adalah proses redistribusi tanah untuk menata penguasaan, pemilikan, penggunaan dan pemanfaatan tanah berdasarkan politik dan hukum pertanahan. AR adalah suatu proses penyediaan akses bagi masyarakat (subjek Reforma Agraria) terhadap segala hal yang memungkinkan masyarakat untuk mengembangkan tanahnya sebagai sumber kehidupan (partisipasi ekonomi- politik, modal, pasar, teknologi, pendampingan, peningkatan kapasitas dan kemampuan.

Dalam pelaksanaan Land Reform mencakup dua komponen yaitu: a) Redistribusi Tanah (land reform) untuk menjamin hak rakyat atas sumber-sumber agraria. Hal ini disebut dengan aset reform, b) Upaya pembangunan lebih luas dapat berkembang secara produktif dan berkelanjutan, hal ini disebut akses form yang mencakup antara lain pemenuhan hak - hak dasar dalam arti luas seperti kesehatan, dan pendidikan, juga penyediaan dukungan modal, teknologi, manajemen, infrastruktur, pasar, dan lain sebagainya (BPN, 2007).

Apabila didekomposisi, dari pengertian Land Reform terdapat lima komponen mendasar di dalamnya, yaitu restrukturisasi penguasaan aset tanah ke arah penciptaan struktur sosial- ekonomi dan politik yang lebih berkeadilan (equity), sumber peningkatan kesejahteraan yang berbasis keagrariaan (welfare), penggunaan/pemanfaatan tanah dan faktor-faktor produksi lainnya secara optimal (efficiency), keberlanjutan (sustanability), dan penyelesaian sengketa tanah (harmony) (BPN, 2007).

\section{METODE}

Pendekatan yang digunakan dalam penelitian ini adalah studi literatur baik dari laporan-laporan penelitian, jurnal dan media massa lainnya. Media massa dipilih sebagai sumber data karena bisa diperoleh dengan mudah dan cepat; bahkan sebagian data diakses melalui internet. Data yang terkumpul dianalisis secara desktiptif. Pengumpulan data dilakukan dilaksanakan selama 6 bulan yakni bulan Juni 2017 - Desember 2017.

\section{HASIL DAN PEMBAHASAN}

Indonesia telah melaksanakan reformasi agraria guna mewujudkan kesejahteraan dan kedaulatan pangan, yang telah dimulai sejak tahun 1961-2005. , Namun dalam implementasi kebijakan agraria banyak menemui kendala, seperti masih tingginya konflik pertanahan yang terjadi dari tahun ke tahun (BPN, 2007). Konflik 
lahan dan sumber daya alam dari tahun ke tahun terus meningkat. Sepanjang 2016, Ombudsman RI mencatat 450 konflik agraria dengan luas 2.829.255 hektar. Perkebunan menduduki peringkat tertinggi, dengan 163 konflik atau 601.680 hektar, terbanyak di perkebunan sawit. Konflik tersebar di 34 provinsi, dengan enam penyumbang konflik tertinggi, antara lain: Riau 44 konflik (9,78\%), Jawa Timur 43 (9,56\%), Jawa Barat 38 (8,44\%), Sumaetra Utara 36 (8,00\%), Aceh 24 (5,33\%), dan Sumatera Selatan 22 (4,89\%).

Hingga saat ini konflik pemanfaatan lahan khususnya lahan perkebunan masih terjadi, bahkan menunjukkan frekwensi yang meningkat. Konflik tersebut adalah konflik antara pengusaha besar, baik yang diusahakan BUMN maupun swasta dengan masyarakat di sekitar perkebunan. Konflik yang telah terjadi selama berabad-abad tersebut menunjukkan gejala yang hampir sama, yaitu tuntutan pengembalian hak rakyat atas tanah perkebunan karena diklaim tanah tersebut diperoleh oleh pihak perkebunan dengan cara "merampas", ataupun pemenuhan pembayaran nilai ganti rugi (tanah) yang dianggap terlalu kecil. Tuntutan tersebut diikuti dengan okupasi tanah oleh masyarakat (termasuk penjarahan).

Jumlah konflik agraria di Provinsi Riau pada tahun 2017 total konflik lahan yang terjadi sebanyak 76 kasus. Konflik terbanyak ada di Pelalawan sebanyak 20 konflik. Kemudian disusul Siak dengan 13 konflik, Indragiri Hilir (Inhil) 8 konflik, Kampar 8 konflik, dan Rokan Hilir (Rohil) 7 konflik," sebut Herry. Sedangkan Kuantan Bengkalis 5 konflik, Singingi 5 konflik, Indragiri Hulu (Inhu) 4 konflik, Rokan Hulu (Rohul) 4 konflik, Kepulauan Meranti 2 konflik. Sedangkan tahun 2016 sebanyak 73 kasus, dibanding tahun 2015 melonjak 55 kasus. Jumlah ini merupakan tertinggi konflik agraria di Riau dalam 4 tahun sebelumnya. Sektor kehutanan dan perkebunan mendominasi konflik, masing-masing 34 kasus. Pada 2015, perkebunan tertinggi, 36 kasus dan kehutanan 18 kasus. Kabupaten paling tinggi konflik adalah Pelalawan 18 kasus, Siak (11) dan Rokan Hilir (10). Konflik juga terjadi karena masalah tapal batas tak jelas antarkabupaten dan antarprovinsi, ada lima kasus. Jika dilihat tipe lahan konsesi, 43 kasus di gambut dan 30 tanah mineral. Riau provinsi paling tinggi konflik sumberdaya se-Indonesia, salah satu penyebab, ketidakjelasan peta yang menjadi rujukan semua pihak. Ketidakterbukaan peta ini, menyebabkan semua pihak seperti punya peta sendiri, bisa saja tumpang tindih (Scale Up, 2017).

Konflik lahan di perkebunan menjadi sektor yang tertinggi jumlahnya yakni 45 konflik dengan luas mencakup 98.043 hektar. Sedangkan sektor kehutanan berjumlah 23 konflik dengan luas 62.634 hektar. Lalu tapal batas ada 8 konflik dengan luas 500 hektar. Dalam konlik lahan ini masyarakat dengan perusahaan juga tercatat tertinggi sebanyak 66\%. Masyarakat selalu berada pada posisi yang dirugikan dan ketidakadilan. Tanah masyarakat dirampas, akses ke hutan hilang, dan tidak adanya kepastian hukum yang diberikan atas ruang kelola. Sedangkan konflik antara pemerintah dengan pemerintah $4 \%$, masyarakat dengan pemerintah $5 \%$, masyarakat dengan cukong $7 \%$, masyarakat dengan masyarakat $8 \%$, dan lainnya $10 \%$. Konflik yang terjadi di Riau disebabkan oleh dua hal yakni: 1) masih adanya pertentangan antara regulasi di instansi pemerintah; 2) penyelesaian konflik yang berlarut-larut karena belum ada mekanisme yang efektif menyelesaikan konflik (Scale Up, 2017). Dalam hubungan ini tidak berlebihan apabila dikatakan bahwa masalah pertanahan di Riau berbeda dengan masalah pertanahan di daerah lain, akan tetapi secara tersirat diakui bahwa masalah pertanahan di Riau adalah akibat dari kebijakan pemerintah pusat. Bahkan pemerintah pusat sangat mempunyai kepentingan terhadap sumber daya alam di Riau yang sangat potensial bagi pembangunan (Yunus, 2013).

Masih terus berlanjutnya konflik agraria, menunjukkan bahwa program reformasi agraria (land reform) di Provinsi Riau khususnya dapat dikatakan sama sekali macet dalam pelaksanaannya. Hal ini terutama disebabkan oleh kurangnya kemauan politik pemerintah dan pemertintah daerah serta kebijakan pembangunan yang lebih mengarah pada upaya mengejar pertumbuhan tanpa memperhatikan pemerataan ekonomi, akibatnya dirasakan oleh rakyat terutama yang tidak memiliki tanah yang semakin terpuruk pada kemiskinan (Asiwijono, 2009). Peran pemerintah daerah sangat lemah dalam penyelesaian konflik hingga masalah makin rumit. Padahal pemerintah punya otoritas lebih luas dalam mengurangi konflik. Pemerintah bisa mencegah agar kasus tak membesar.

Menurut (Fauzi, 2008), konflik tanah perkebunan merupakan persoalan klasik yang timbul sejak perkebunan ada di Indonesia. Pasca kemerdekaan, konflik menjadi semakin kompleks karena selain mewarisi persoalan dari masa sebelumnya juga karena semakin kompleksnya persoalan-persoalan politik dalam negeri. Penyelesaian konflik tanah perkebunan dapat dimulai dengan melakukan pembenahan administrasi tanah perkebunan yang belum tertata baik sejak kemerdekaan.

Dipedesaan, hampir $85 \%$ petani gurem di Indonesia adalah petani tanpa tanah dan lahan sempit dengan kepemilikan rata-rata $0,25 \mathrm{Ha}$, sehingga melahirkan dan menyuburkan konflik agraria. Petani dan warga yang tidak bertanah tidak akan mampu berproduksi dan kondisi tersebut diperparah dengan keberpihakan 
aparatur terhadap kepentingan pemilik modal dalam menjaga assetnya. Akibatnya sering terjadi bentrok antar warga dan pemilik modal yang mengakibatkan jatuh korban hanya karena ingin memperjuangkan kehidupan dan kelangsungannya, agar tidak menjadi makin miskin (Syahyuti, 2006). Oleh sebab itu pemerintah pada periode 2014-2019 menargetkan, 12,7 juta hektar hutan buat masyarakat dan redistribusi lahan 9 juta hektar. Targetnya, petani gurem tak memiliki tanah atau kepemilikan kurang 0,3 hektar.

Reformasi agraria tidak boleh dipahami sebagai proyek bagi - bagi tanah semata, tapi harus diorientasikan pada upaya peningkatan kesejahteraan petani serta revitalisasi pertanian dan pedesaan secara menyeluruh. Untuk itu selain harus merupakan upaya penataan struktural untuk menjamin hak rakyat atas sumber- sumber agraria melalui Land Reform. Land Reform harus merupakan upaya pembangunan lebih luas yang melibatkan multi-pihak untuk menjamin agar aset tanah yang telah diberikan dapat berkembang secara produktif dan berkelanjutan. Hal ini mencakup pemenuhan hak-hak dasar dalam arti luas, misalnya pendidikan, kesehatan dan juga penyediaan dukungan modal, teknologi, manajemen, infrastruktur, pasar dan lain -lain. Komponen yang pertama disebut sebagai asset reform, sedangkan yang kedua disebut access reform. Gabungan antara kedua jenis reform inilah yang dimaksud dengan Land Reform plus (Suprianto, 2008). Selama ini, Kementerian Agraria dan Tata Ruang/BPN tampak hanya mengejar target sertifikasi bidang tanah. Dengan Peraturan Menteri ATR soal tata cara penetapan hak komunal atas tanah masyarakat hukum adat dan masyarakat yang berada dalam kawasan tertentu. Reforma agraria Kementerian ATR/BPN seakan dikontrol pasar. Satu sisi, pemerintah komitmen redistribusi lahan, tetapi cenderung mempermudah investasi, seperti bisnis sawit. Selain peraturan Presiden soal pelaksanaan reforma agraria belum juga selesai. Reforma agrariapun, katanya, masih jadi agenda politik, bukan peningkatan kesejahteraan masyarakat.

Ada tiga hal penting yang perlu dilakukan segera terkait lahan. Pertama, dalam rangka reformasi agraria yang disatu sisi, bertujuan memerangi kemiskinan (ini adalah salah satu prinsip dalam pelaksanaan reformasi agraria, dan sisi lain, dengan penyesuaian terhadap perkembangan di dalam negeri dan global sejak periode 1960-an hingga saat ini, UU Pokok Agraria No. 5 / 1960 yang diperkuat dengan Ketetapan MPR No.IX/2001 tentang Pembaharuan Agraria dan Sumberdaya Alam, harus direvisi dan hasilnya harus dijalankan secara konsisten dan tegas. Revisi tersebut bisa dalam bentuk mengeluarkan UU Reformasi Agraria, dan harus dilakukan secepatnya guna menambal kebolongan hukum terkait operasionalisasi program reformasi agraria. Program pembaharuan agraria nasional yang direncanakan oleh pemerintah membutuhkan dasar hukum yang kuat dan komprehensif (Tulus, 2010). Kedua, pembagian lahan seluas 8,15 juta ha tersebut harus diiringi dengan pemberdayaan penerimanya agar mampu memanfaatkannya secara optimal, yakni menghasilkan usaha yang produktif. Selain itu, harus ada pengawasan yang ketat, karena ada indikasi banyaknya tanah yang dibagikan itu dijual, digadaikan, atau diijonkan oleh penerimanya. Ketiga, proses sertifikasi lahan pertanian juga harus dipercepat atau dipermudah; rencana tata ruang harus melindungi lahan pertanian yang produktif dan subur; dan pembelian lahan pertanian secara paksa atau untuk tujuan yang sebenarnya tidak terlalu penting (seperti lapangan golf, apartemen mahal, pertokoan mewah) harus dihentikan (Entang, 2006).

Sebagaimana dituangkan dalam Undang-Undang Pokok Agraria, telah ditetapkan garis-garis besar reformasi di bidang pertanahan yang dirangkum dalam Panca Program Agraria Reform Indonesia, yang meliputi: 1) Pembaharuan Hukum Tanah, melalui penciptaan unifikasi hukum yang berkonsepsi nasional, dengan menyediakan hak-hak atas tanah untuk berbagai keperluan pemerintah, perseorangan serta badanbadan usaha, sosial dan keagamaan disertai pemberian jaminan kepastian hukum dengan penyelenggaraan pendaftaran tanah; 2) Penghapusan hak-hak asing dan konsesikonsesi kolonial atas tanah yang dialihkan kepada penguasa-penguasa nasional; 3) Mengakhiri penghisapan feodal secara berangsurangsur; 4) Perombakan pemilikan dan penguasaan tanah serta hubungan-hubungan hukum yang bersdangkutan dengan penguasaan tanah, dalam mewujudkan pemerataan kemakmuran dan keadilan yang kemudian dikenal sebagai program landreform; 5) Perencanaan, persediaan dan peruntukan tanah serta penggunaannya secara terencana, sesuai dengan daya dukung dan kemampuannya yang kemudian dikenal sebagai kegiatan penata-gunaan tanah (Sodiki, 2014).

Implementasi kebijakan publik di bidang pertanahan nasional dari berbagai rezim yang ada sangat determinan oleh faktor kepentingan politik. Oleh karena itu dalam evaluasi implementasi kebijakannya perlu diadakan pembaruan yang berkeadilan, kesejahteraan, dengan prinsip-prinsip desentralisasi, good governance dalam pengelolaan sumber daya tanah. Semua ini tentunya dalam rangka mencapai tujuan bersama yaitu mencapai masyarakat yang adil dan makmur berdasarkan Pancasila dan UUD 1945 (Rahmi, 2011). Berdasarkan data yang dihimpun dari berbagai pihak yang berhubungan dengan konflik pertanahan di Propinsi Riau. Setelah dilakukan penelusuran ternyata terdapat beberapa instansi dan badan yang mengurusi persoalan yang berkaitan dengan konflik pertanahan, seperti Badan Pertanahan, Kementrian Kehutanan 
(Dinas Kehutanan), Dinas Perkebunan bahkan pada masing-masing instansi dan badan ada bagian yang khusus menangani persoalan konflik yang berhubungan dengan pertanahan, seperti di BPN ada bagian yang menangani sengketa dan konflik pertanahan, di Dinas Perkebunan terdapat Kasi Pengamanan kebun.

Salah satu pendekatan untuk meningkatkan kesejahteraan petani sehingga keluar dari perangkap kemiskinan adalah peningkatan akses penguasaan lahan oleh petani. Berdasarkan kondisi penguasaan lahan saat ini kebijakan reforma agraria untuk meningkatkan lahan petani perlu diimplementasikan secara nyata untuk mensejahterakan rumah tangga petani kecil (Susilowati, S dan M. Maulana, 2012). Secara teoritis, ada empat faktor penting sebagai prasyarat pelaksanaan landreform, yaitu kesadaran dan kemauan dari elit politik, organisasi petani yang kuat, ketersediaan data yang lengkap, serta dukungan anggaran yang memadai. Saat ini, kondisi keempat faktor tersebut masih dalam kondisi lemah, sehingga dapat dikatakan implementasi landreform secara serentak dan menyeluruh masih sulit diwujudkan (Sodiki, 2014). Penciptaan balance kepentingan antara kepentingan masyarakat dan pemodal, sangat ditentukan oleh politikal wil pemerintah dalam keberpihakan yang sama terhadap keduanya. Dalam hal ini, posisi pemerintah seharusnya lebih mendapat porsi sebagai pengawas dari dua kepentingan dari dua kelompok tersebut. Untuk itu sangat diperlukan adanya di perubahan paradigma hubungan antara tripatrit (Yunus, 2013).

Penyelesaian konflik yang terjadi menurut tokohtokoh Lembaga Adat Melayu Riau harus dilakukan dengan prinsip berwawasan nasional artinya keputusan yang diambil justru diharapkan menjadi perekat kebersamaan, kesetiakawanan, solidaritas sesama anak bangsa. Penyelesaian haruslah yang adil dan beradab berdaya guna dan berhasil guna untuk kesejahteraan masyarakat. Serta penyelesaian konflik itu harus mempunyai kekuatan hukum yang dapat mengikat mereka yang bersengketa, sehingga tercipta keamanan dan ketertiban dalam masyarakat. Menurut Yunus (2013), adapun langkah penyelesaian konflik pertanahan di Propinsi Riau yang harus diambil adalah:

1. Mengukur ulang terhadap izin HGU yang sudah terlanjur diterbitkan baik perkebunan besar, hutan tanaman industri, sehingga akan dapat diketahui secara pasti kebenarannya secara akurat.

2. Peninjauan kembali terhadap HGU baik perkebunan maupun HTI yang diberikan baik jumlah luas yang diberikan untuk dibatasimaupun izin yang sudah habis untuk tidak dilakukan perpanjangan izin sehingga masyarakat memiliki kesempantan untuk memiliki lahan untuk berusaha yang selama ini sudah dirampas oleh pengusaha dan pemerintah dengan alasan demi untuk kepentingan nasional dan negara.

3. Bentuk kerjasama yang dianggap ideal apabila perusahaan pemegang HGU bersedia membangun kerjasama dengan masyarakat melalui perusahaan milik desa. Pilihan ini walaupun bersifat ekonomi, namun dirasa dapat memupuk hubungan baik antara perusahaan dengan masyarakat setempat. Termasuk terhadap pemanfaatan bekas tanah pemegang HGU yang sudah habis masa berlakukan, diberikan kepada Badan Usaha Milik Desa untuk dikelola sendiri atau dengan bekerja sama dengan perusahaan lain yang memiliki modal untuk itu.

\section{KESIMPULAN}

Reformasi agraria masih penting dilakukan di Provinsi Riau, mengingat masih tingginya terjadi kasus konflik lahan atau tanah. Faktor penyebabnya antara lain disebabkan, ketidakjelasan peta yang menjadi rujukan semua pihak. Berpedoman pada kebijakan pertanahan nasional, maka implementasi pengelolaan sumberdaya agraria harus dilaksanakan melalui 6 (enam) kegiatan yaitu: 1) penatagunaan tanah, 2) pengaturan penguasaan tanah, 3) pendataan bidang tanah, 4) pemberian hak atas tanah, 5) pendaftaran hak atas tanah dan peralihannya (sertifikasi) serta 6) penyelesaian sengketa pertanahan. Implementasi pengelolaan suberdaya agraria tersebut diatas, membutuhkan administrasi basis data yang tepat, akurat dan kuat. Oleh sebab itu membangun sistem administrasi pertanahan mendesak untuk dilakukan. Sistem informasi pertanahan (SIP) merupakan sebuah kebutuhan yang mendesak untuk mewujudkan catur tertib pertanahan di daerah. Oleh karena itu, perlu dibangun SIP yang berbasis desa/kelurahan pada pemerintahan kabupaten/kota dengan menyusun grand design sistem informasi pertanahan secara nasional.

\section{DAFTAR PUSTAKA}

Asiwijono, S. 2009. Reformasi Bidang Pertanian Memimpikan Kemandirian Petani Indonesia. Yogyakarta: Mardi Mulyo.

BPN. 2007. Program Badan Pertanahan Nasional tahun 2007. Jakarta: Badan Pertanahan Nasional RI. 
Entang, S. 2006. Petani di Tanah Merdeka. Bogor: Petani Center.

Fauzi, N. 2008. Gelombang aru Reforma AGraria di Awal Abad ke 21. Agenda Pembaruan Agraria dan Tirani Modal, dalam Rangka Konperensi Warisan Toritarianisme: Demokrasi dan Tirani Modal. FISIP-UI Depok Jakarta.

Harsono, B. 2003. Undang-Undang Pokok Agraria, Sejarah Penyusunan, Isi dan Pelaksanaanya. Bagian I. Jilid I. Jakarta: Djambatan.

Lemhamnas. 2014. . Revitalisasi Kebijakan Agraria Guna Meningkatkan Kesejahteraan Rakyat dalam Rangka Ketahanan Nasional. Kajian Lemhamnas RI, Edisi 14: 21-32.

Noer, F. 1999. Petani dan Penguasa, Perjalanan Politik Agraria Indonesia. Yogyakarta: Pustaka Pelajardan Insit Press dan Konsorsium Pembaharuan Agraria.

Rahmi, E. 2011. Hukum Pertanahan dalam Sistem Hukum Indonesia. Bandung: UNPAD-Press.

Ramadhiani, A. 2017. Riau, Provinsi dengan Konflik Agraria Terbanyak. https://properti.kompas/read/2017/01/05/202000221/riau.provinsi.dengan.konflik.agraria.terbanyak Diakses pada 10 Oktober 2017.

Scale Up. 2017. Scale Up Catat Konflik Lahan Riau Meningkat, Pelalawan Tertinggi. http://www.riau24.com/berita/baca/83237-scale-up-catat-konflik-lahan-riau-meningkat-pelalawan-tertinggi/ Diakses pada 21 September 2017.

Sembiring. 2009. Konflik Tanah Perkebunan di Indonesia. Jurnal Hukum 16(3): 337-353.

Sodiki, A. 2014. Menyejahterahkan Rakyat Lewat Land Reform. Jurnal Land Reform, Edisi I: 27-36.

Sukino. 2013. Membangun Pertanian dengan Pemberdayaan Masyarakat Tani. Yogyakarta: Pustaka Baru Press.

Supriyanto. 2008. Implementasi Kebijakan Pertanahan Nasional. Jurnal Dinamika Hukum 8(3): 81-91.

Susilowati, S., dan M. Maulana. 2012. Luas Lahan Usahatani dan Kesejahteraan Petani: Eksistensi Petani Gurem dan Urgensi Kebijakan Reforma Agraria. Analisis Kebijakan Pertanian 10(1): 75-89.

Syahyuti. 2006. Nilai-Nilai Kearifan pada Konsep Penguasaan Tanah menurut Hukum Adat di Indonesia. Forum Penelitian Agro Ekonomi 24(2): 14.

Tulus, T. 2010. Pembangunan Pertanian dan Ketahanan Pangan. Jakarta: Universitas Indonesia-Press.

Yunus, M. 2013. Konflik Pertanahan dan Penyelesaiannya menurut Adat di Provinsi Riau. Menara 12(1): 23-41.

Winoto, J. 2006. Laporan Seminar Nasional Penataan Ulang Kelola Sumberdaya Agraria sebagai Upaya Peningkatan Kualitas Daya Dukung dan Kemakmuran Rakyat (hal.8). Jember: Universitas Jember.

Wiradi, G. 2000. Reforma Agraria Perjalanan Yang Belum Berakhir, Lapera Pustaka Utama, Yogyakarta. 2000. Yogyakarta: Lapera Pustaka Utama. 